

Original Research Article

https://doi.org/10.20546/ijcmas.2017.607.076

\title{
Standardization of Growing Media for the Hydroponic Cultivation of Tomato
}

\author{
T. Reshma* and P.S. Sarath \\ Kerala Agricultural University, Vellanikkara, Thrissur - 680656, Kerala, India \\ *Corresponding author
}

\section{A B S T R A C T}

Keywords

Ebb and flow technique, Coco peat, Hydroponics, Water holding capacity, Expanded clay pellets, Tomato.

Article Info

Accepted:

14 June 2017 Available Online: 10 July 2017
The tomato variety Anagha was raised in Ebb and flow hydroponic system (flood and drain system) at Department of Olericulture, College of Horticulture, Vellanikkara to evaluate the ideality of growing media (coco peat, expanded clay pellets and pebbles). Plants grown in coco peat medium performed the best in terms of yield per plant $(1.67 \mathrm{~kg})$, average fruit weight $(45.86 \mathrm{~g})$, plant height $(69.36 \mathrm{~cm})$, crop duration (85.73 days) etc. followed by pebbles. The coco peat medium contained comparatively high amount of potassium $(0.36 \%)$ and also possessed high water holding capacity. Performance of plants grown in expanded clay pellets was very poor. Fruit quality in terms of total soluble solid content and titrable acidity was not significantly affected by the treatments.

\section{Introduction}

Hydroponics is an efficient technology for growing plants in nutrient solutions (water containing fertilizers), with or without the use of an artificial medium (sand, gravel, vermiculite, rockwool, perlite, peatmoss, coir, or sawdust) (Jensen and Collins, 1985). Portela and Bartoloni (1997) carried out an experiment at University of Buenos Aires, Argentina, and they reported that tomatoes produced early, total and higher marketable yield under hydroponic culture compared to soil (total yields 3.0 and $2.4 \mathrm{~kg} / \mathrm{plant}$ respectively). A study to compare the performance of tomato cultivars under soilless and soil production systems by Maboko and Plooy (2009) revealed that, tomato plants in the soilless system developed faster with higher total yield and quality compared to those under soil cultivation. The average marketable yield under soilless cultivation was 92.1 per cent, while in soil cultivation it was only 77.0 per cent.

The main attraction of hydroponics is that, it does not demand any fertile soil for the production of crops. Since the soil is excluded from production process there will not be any problem related to soil born diseases, pests and weeds. By the exclusion of these problems, there will be minimum usage of harmful plant protection chemicals, so the yield from hydroponics is fresh and healthy (Bogovic, 2011). Even though, soil is excluded from hydroponics, most of the 
plants, demand a supporting medium for better holding in the structure. Based on this, hydroponics can be divided into liquid hydroponic systems (no other supporting medium for the plant roots) and aggregate hydroponic systems (have a solid medium of support) (Gorbe and Calatayud, 2013). Borji et al., (2010), found that the substrate prepared by mixing date palm peat and coir peat gave significantly higher yield for tomatoes compared to other substrates in hydroponics, in an experiment held at the greenhouse of Islamic Azad University, Khorasgan, Iran. An experiment carried out at Agricultural Research Institute, Cyprus showed that the use of local gravel for the hydroponic cultivation of tomato produced similar yield to those with imported perlite (Neocleous and Polycarpou, 2010). Joseph and Muthuchamy (2014) stated that tomatoes yielded 245.3 t/ha when grown under hydroponic system in a trough with coco peat, gravel and silex stone as media in their study on productivity, quality and economics of tomato (Solanum lycopersicum) cultivation in aggregate hydroponics.

The study on lignite as a medium in soilless cultivation of tomato showed that, under hydroponics tomato plants produced highest early marketable and total yield when grown in lignite media and this was not significantly different from the marketable yield obtained under coir pith (Dysko et al., 2015).

Now a day, in Kerala, more people from urban areas are showing interest towards modern techniques in agriculture. The changing health concern of people also demands high quality food. But in a state like Kerala, where there is severe shrinking of cultivable land and water, the production of fresh vegetables is great challenge. All these, forces the adoption of techniques which produce more yields from less area and techniques which does not demand productive soil for cultivation. Hence a preliminary study was carried out to standardize the ideal growing media for the hydroponic cultivation of tomato in rain shelter.

\section{Materials and Methods}

The present investigation was carried out in the Department of Olericulture, College of Horticulture, Vellanikkara during September 2015 to January 2016. The objective of this study was to standardize an ideal growing media for the hydroponic cultivation of tomato under rain shelter. The experiment was laid out using Completely Randomized Design (CRD). There were three replications and 15 plants per replication. Seeds of the semi determinate tomato variety Anagha was sown in protrays during 2015, September and transplanted in 2015, October. For understanding the ideality of growing medium, three types of growing media were tested in ebb and flow hydroponic system (flood and drain system) which was designed by the researchers in Kerala Agricultural University supplying by supplying Cooper's nutrient solution.

In Ebb and flow technique, seedlings were directly transplanted in to brick structures filled with different growing media (coco peat, expanded clay pellets and pebbles) (Plate 1, Plate 2, and Plate 3). There were five rows and ten plants in each row, with a total of 50 plants in each structure. The nutrient solution was pumped in to the structure in such a manner that, it should get completely flooded through the medium for 20 minutes. Then the nutrient solution was drained back into the main tank and the process was repeated continuously. The flood and drain time was controlled by a timer, for which the ' $\mathrm{ON}$ ' time was 20 minutes and 'OFF' time was 10 minutes. Observations on growth characters, yield characters and quality characters were taken from the experimental plants during the course of experiment. 


\section{Treatment details}

$\mathrm{F}_{1}$ - Ebb and flow method

$\mathrm{S}_{1}$ - Cooper's nutrient solution

$\mathrm{M}_{1}$ - Coco peat medium

$\mathrm{M}_{2}$ - Expanded clay pellet medium

$\mathrm{M}_{3}$ - Pebble medium

\section{Treatment combinations}

$\mathrm{F}_{1} \mathrm{~S}_{1} \mathrm{M}_{1}-$ Ebb and flow method + Cooper's nutrient solution + Coco peat medium

$\mathrm{F}_{1} \mathrm{~S}_{1} \mathrm{M}_{2}-$ Ebb and flow method + Cooper's nutrient solution + Expanded clay pellet medium

$\mathrm{F}_{1} \mathrm{~S}_{1} \mathrm{M}_{3}-$ Ebb and flow method + Cooper's nutrient solution + Pebble medium

\section{Results and Discussion}

\section{Growth characters}

The data on growth characters are presented in table 1. The nature of growing media significantly influenced the plant height. Maximum plant height was observed coco peat $(69.36 \mathrm{~cm})$. This was followed by pebbles $(66.40 \mathrm{~cm})$. The plant height was the lowest in expanded clay pellets $(63.00 \mathrm{~cm})$. The minimum days to first flower appearance was observed in coco peat medium (22.06 days), which was followed by pebble medium (24.36 days). Since the first flower appearance was minimum in coco peat medium, the days to first fruit set (25.73 days) and first harvest (51.73) was also minimum in this medium. The influence of growing media on the duration of the crop was significant. Tomato plants in coco peat medium had the highest duration (85.73 days).

\section{Yield characters}

The data on yield characters are presented in table 2. Growing media significantly influenced fruits per plant. In coco peat plants produced maximum number of fruits (36.50). This was followed by pebbles (34.36). Fruits per plant were minimum in expanded clay pellets (20.10). Influence of growing media on the number of harvest was significant. Number of harvest was the highest in coco peat medium (20.16), followed by pebble medium (16.03). The nature of growing media significantly influenced yield per plant. The highest yield per plant was observed in coco peat medium $(1.67 \mathrm{~kg})$. The average fruit weight was significantly influenced by growing media. It was observed to be the highest in coco peat medium ( $45.86 \mathrm{~g}$ ) and the lowest in expanded clay pellets medium $(25.73 \mathrm{~g})$.

\section{Quality characters}

The data on quality characters are presented in table 3. The nature of growing media did not influence the TSS and acidity of fruits significantly. The TSS and acidity varied from $7.50-7.83$ and $0.56-0.59$ respectively.

Plate.1 Tomato plant in coco peat medium

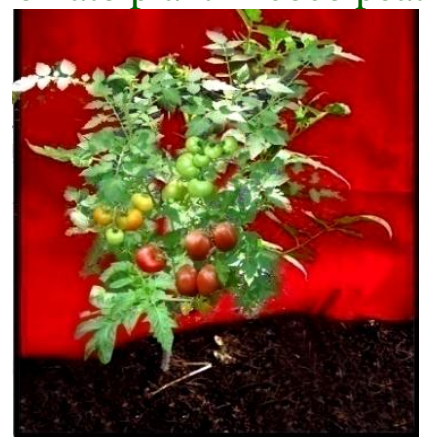


Plate. 2 Tomato plant in expanded clay pellet medium

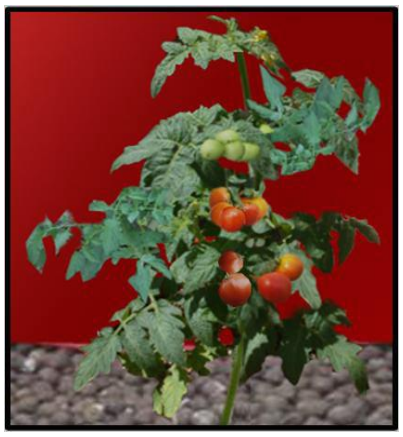

Plate.3 Tomato plant in pebble medium



Table.1 Growth characters of tomato in Ebb and flow system

\begin{tabular}{|c|c|c|c|c|c|}
\hline Medium & $\begin{array}{c}\text { Plant height } \\
\text { at } 60^{\text {th }} \text { day } \\
(\mathrm{cm})\end{array}$ & $\begin{array}{c}\text { Days to first } \\
\text { flower } \\
\text { appearance }\end{array}$ & $\begin{array}{c}\text { Days to first } \\
\text { fruit set }\end{array}$ & $\begin{array}{c}\text { Days to first } \\
\text { harvest }\end{array}$ & $\begin{array}{c}\text { Duration } \\
\text { of the crop }\end{array}$ \\
\hline Coco peat & 69.36 & 22.06 & 25.73 & 51.73 & 85.73 \\
\hline $\begin{array}{c}\text { Expanded } \\
\text { clay pellets }\end{array}$ & 63.00 & 25.73 & 29.40 & 56.06 & 82.50 \\
\hline Pebbles & 66.40 & 24.36 & 27.70 & 54.40 & 84.13 \\
\hline CD $(0.05)$ & 2.21 & 1.23 & 1.30 & 1.57 & 1.12 \\
\hline
\end{tabular}

Table.2 Yield characters of tomato in Ebb and flow system

\begin{tabular}{|c|c|c|c|c|}
\hline Medium & $\begin{array}{c}\text { Fruits per } \\
\text { plant }\end{array}$ & $\begin{array}{c}\text { Number of } \\
\text { harvests }\end{array}$ & $\begin{array}{c}\text { Yield per plant } \\
(\mathrm{kg})\end{array}$ & $\begin{array}{c}\text { Average fruit } \\
\text { weight }(\mathrm{g})\end{array}$ \\
\hline Coco peat & 36.50 & 20.16 & 1.67 & 45.86 \\
\hline $\begin{array}{c}\text { Expanded clay } \\
\text { pellets }\end{array}$ & 20.10 & 9.83 & 0.51 & 25.73 \\
\hline Pebbles & 34.36 & 16.03 & 1.48 & 43.43 \\
\hline CD $(0.05)$ & 1.30 & 0.97 & 0.05 & 1.11 \\
\hline
\end{tabular}


Table.3 Quality characters of tomato in Ebb and flow system

\begin{tabular}{|c|c|c|}
\hline Medium & TSS $(\circ$ Brix $)$ & Acidity (\%) \\
\hline Coco peat & 7.50 & 0.56 \\
\hline Expanded clay pellets & 7.83 & 0.59 \\
\hline Pebbles & 7.73 & 0.56 \\
\hline CD $(0.05)$ & NS & NS \\
\hline
\end{tabular}

The better performance of tomato plants in coco peat medium may be due to, the high water holding capacity, aeration and slightly high potassium content in this medium. The studies conducted by various researchers also reported that, growing media had significant effect on the growth and yield of crops growing in it (Padem et al., 1994; Peyvast et al., 2007; Peyvast et al., 2010). The study carried out by Noguera et al., (2000), revealed that coconut waste was the best medium for growing horticultural crops under hydroponics.

They observed that this medium was light in weight and had high total porosity (94 per cent of total volume). Coco peat also exhibited high air content. $\mathrm{pH}$ was found to be slightly acidic and EC varied between 0.4 and $6.0 \mathrm{dS} / \mathrm{m}$. Cation exchange capacity ranged from 32 to 95 m.e./100 $\mathrm{g}$ and $\mathrm{C} / \mathrm{N}$ ratio averaged to 117 .

The amount of naturally-occurring available nutrients like mineral nitrogen, calcium and magnesium was low but phosphorus and potassium contents were high. Yau and Murphy (2000) reported that when composted coco peat was used as the growing medium for tomato plants under soilless culture, they produced higher dry root weight $(22 \%)$, fruit number (43\%) and total yield (64\%).

In an experiment conducted by Colla et al., (2003) on soil less cultivation of cucumbers, it was observed that under coir pith and perlite media the overall yield was high. The average number of fruits, yield per plant and average fruit weight were found to be higher in these media. When coconut fiber was used as the growing medium in hydroponics, tomato crop yielded the heaviest fruits $(128 \mathrm{~g})$ (Carrijo et al., 2004).

The NPK analysis carried out for coco peat during the experiment revealed that it contained $0.32 \%$ of nitrogen, $0.01 \%$ of phosphorus and $0.36 \%$ of potassium. Handreck (1993) also reported that, the higher percentage of potassium in coco peat improved the performance of tomato plants in soilless culture.

The high potassium content in coconut coir dust improved the fruit size in tomatoes. According to Cresswell (2002), coconut coir dust can be used as an alternative for peat in soil less culture, due to its properties like high amount of potassium, less acidic nature, high air filled porosity, high water holding capacity, better capillary wetting and physical stability.

In conclusion, the above findings revealed that, when coco peat was used as the growing medium tomato plants produced higher vegetative growth and yield per plant, providing that the quality of growing substrates greatly matters when crops are grown under hydroponically.

The higher potassium content and better water holding capacity of coco peat medium significantly influenced the performance of plants under hydroponics. 


\section{References}

Bogovic, M. 2011. Hydroponic vegetable growing. Messenger Plant Prot. 34 (6): 1216.

Borji, H., Ghahsareh, A. M., and Jafarpour, M. 2010. Effects of the substrate on tomato in soilless culture. Res. J. Agric. Biol. Sci. 6 (6): 923-927.

Carrijo, O. A., Vidal, M. C., Reis, N. V., Souza, R. B. D., and Makishima, N. 2004. Tomato crop production under different substrates and greenhouse models. Hortic. Brasileira 22(1): 5-9.

Colla, G., Saccardo, F., Rea, E., Pierandrei, F., and Salerno, A. 2003. Effects of substrates on yield, quality and mineral composition of soilless-grown cucumbers. In: Proceedings of the VI International Symposium on Protected Cultivation in Mild Winter Climate: Product and Process Innovation, pp. 205-209.

Dysko, J., Kaniszewski, S., and Kowalczyk, W. 2015. Lignite as a new medium in soilless cultivation of tomato. J. Elementology 20 (3): $559-569$

Cresswell, G. 2002. Coir dust a proven alternative to peat. In: Proceedings of the Australian Potting Mix Manufacturers Conference, Sydney, pp. 1-5.

Gorbe, E. and Calatayud, A. 2013. Optimization of nutrition in soilless systems: a review. Adv. Bot. Res. 53: 193-245.

Handreck, K. A. 1993. Properties of coir dust, and its use in the formulation of soilless potting media. Commun. Soil Sci. Plant Anal. 24(3): 349-363.

Jensen, M. H., and Collins, W. L. 1985. Hydroponic vegetable production. Hortic. Rev. 7,483-558.

Joseph, A. and Muthuchamy, I. 2014. Productivity, Quality and economics of tomato cultivation in aggregated hydroponics- A case study from Coimbatore region of Tamil Nadu. Indian.J. Sci. Tech. 7(8): 1078-1086.

Maboko, M. M. and Plooy, C. P. 2009. Comparative performance of tomato cultivars in soilless Vs. insoil production system. Acta Hortic. 843: 314-318.

Neocleous, D. and Polycarpou, P. 2010. Gravel for soil less tomato culture in Mediterranian. Int. J. Veg. Sci.16 (2): 148159.

Noguera, P., Abad, M., Noguera, V., Puchades, R., and Maquieira, A. 2000. Coconut coir waste, a new and viable ecologicallyfriendly peat substitute. In: Herregods, M., Boxus, P., Baets, W., and Jager, A. (eds), Proceedings of the XXV International Horticultural Congress. Part 7. Quality of horticultural products: starting material, auxiliary products, quality control, Brussels, Belgium, pp. 279-286.Padem, H., and Alan, R. 1994. The effect of some substrates on yield and chemical composition of pepper under greenhouse conditions. Acta Hortic. 66: 445-451.

Peyvast, G.H., Noorizadeh, M., Hamidoghli,.J, and Ramezani-Kharazi, P. 2007. Effect of four different substrates on growth, yield and some fruit quality parameters of cucumber in bag culture. Acta Hortic. 742: 175-182.

Peyvast, G.H., Olfati, J.A., Kharazi, P.R., and Roudsari, O.N. 2010. Effect of substrate on greenhouse cucumber production in soilless culture. Acta Hortic. 871: 429-436.

Portela, S. and Bartoloni, F. 1997. Greenhouse tomato cultivation: comparison of traditional and hydroponic methods. Riv. la Facultated de Agron. 16(3):193-198.

Yau, P.Y. and Murphy, R.J. 2000. Biodegraded coco peat as a horticultural substrate. Acta Hortic. 517: 275- 278.

\section{How to cite this article:}

Reshma, T. and Sarath, P.S. 2017. Standardization of Growing Media for the Hydroponic Cultivation of Tomato. Int.J.Curr.Microbiol.App.Sci. 6(7): 626-631. doi: https://doi.org/10.20546/ijcmas.2017.607.076 